\title{
De un arte crítico a un arte socialista: el itinerario de León Ferrari y Ricardo Carpani como síntoma de las transformaciones históricas de la relación entre el arte y la política en Argentina (y América Latina) durante los años sesenta y setenta
}

\author{
Jaime VINDEL GAMONAL ${ }^{1}$ \\ Historiador del Arte \\ Universidad de Salamanca \\ vindel.jaime@gmail.com
}

Recibido: 02-03-2012

Aceptado: 22-10-2012

\section{RESUMEN}

Es difícil entender el fenómeno de radicalización de la escena artística argentina en el arco temporal que se extiende desde finales de los años cincuenta a principios de la década del setenta sin acudir al itinerario intelectual de dos artistas como Ricardo Carpani y León Ferrari. Ambos ejercieron una poderosa influencia sobre el sector del campo artístico nacional y latinoamericano más interesado por el arraigo social e histórico de sus obras, estableciéndose como verdaderos núcleos gravitacionales de la comprensión y el devenir de las relaciones entre el arte y la política durante el período.

Palabras clave: arte, política, latinoamérica, vanguardia, antiintelectualismo.

From a Critical Art to a Socialist Art: the Itinerary of León Ferrari and Ricardo Carpany as a Symptom of the Historical Transformations of the Relationship Between Art and Politics in Argentina (and Latin America) During the Sixties and Seventies

\begin{abstract}
It would be difficult to attempt to understand the radicalisation of the Argentinean art scene in the time spanning from the late fifties to the early seventies without turning to the intellectual career of two artists: Ricardo Carpani and León Ferrari. Both men exercised a marked influence over their contemporaries, becoming gravitational centres in the understanding and the development of the connections between art and politics during the period.
\end{abstract}

Key words: Art, Politics, Latin America, Vanguard, Anti-Intellectualism.

\footnotetext{
1 Miembro del proyecto I+D "Imágenes del arte y reescritura de las narrativas en la cultura visual global" (Aurora Fernández Polanco). 
Con un ánimo polémico, Ricardo Carpani se preguntaba hace algunos años, en una entrevista con Ana Longoni y Mariano Mestman, si estaba justificada la conversión en mito de la historia de la vanguardia argentina de los años sesenta, cuyo trayecto había concluido en la experiencia colectiva Tucumán Arde. Tucumán Arde aglutinó a un conjunto de artistas mayoritariamente procedentes de las escenas artísticas de Buenos Aires y Rosario - donde habían obtenido visibilidad bajo el amparo de centros de arte como el Instituto Di Tella- con el objetivo de crear una red de contrainformación que revelara la crisis de subsistencia que por entonces sufría la homónima provincia argentina, agravada por el cierre de sus ingenios azucareros y silenciada por los medios de comunicación controlados por la dictadura de Juan Carlos Onganía. En una primera etapa, los artistas -que contaron con el apoyo de especialistas procedentes de otras disciplinas, entre los que destacaron los sociólogos del CICSO (Centro de Investigaciones en Ciencias Sociales de la Universidad de Buenos Aires)- realizaron un trabajo de campo con el objetivo de recabar información de primera mano sobre la situación de la provincia tucumana. La enorme y variada cantidad de material recopilado fue presentada, tras una campaña de difusión pública, en sendas muestras, que tuvieron lugar en los locales de Rosario y Buenos Aires del sindicato no oficialista de la CGT (Confederación General de los Trabajadores) de los Argentinos y cuyo propósito declarado era hallar un nuevo público que potencialmente pudiera transformarse en el sujeto del cambio revolucionario (figs. 1 y 2).

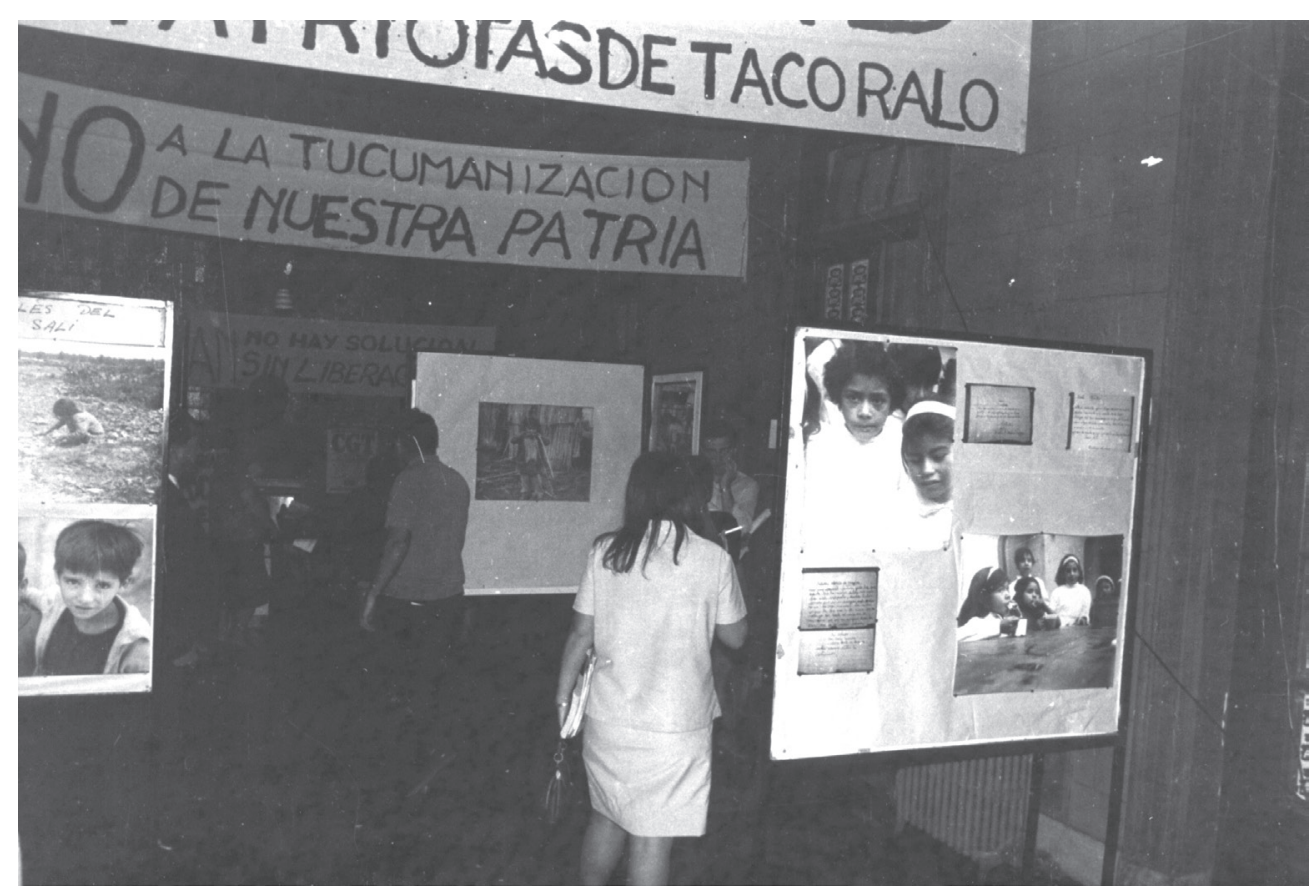

Fig. 1: Tucumán Arde, muestra en la CGT de Rosario: paneles en los que se mostraban parte de las imágenes y de la información recopilada por los artistas durante los viajes a la provincia de Tucumán, 1968. 


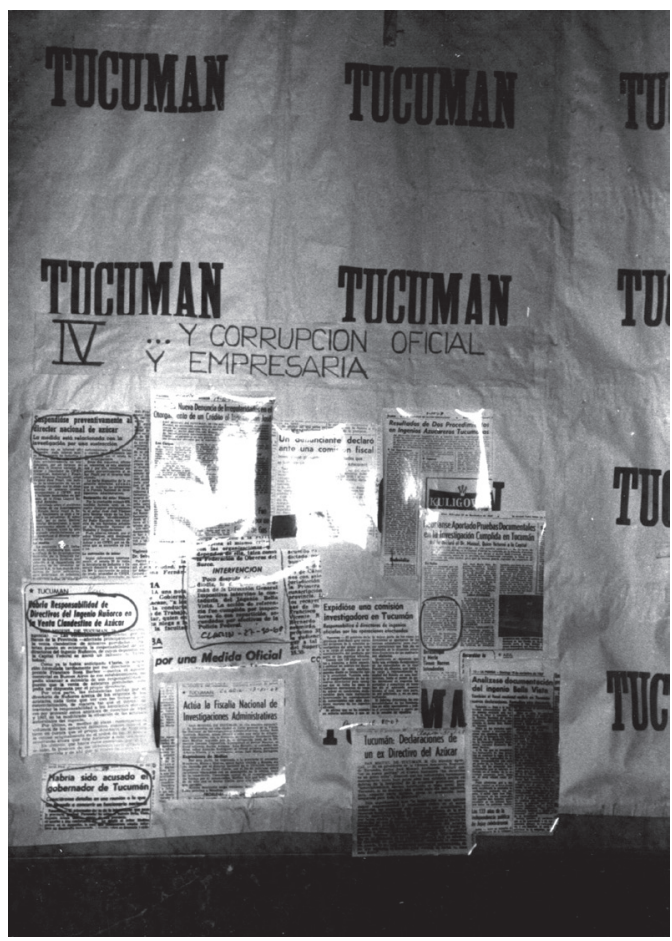

Fig. 2: Tucumán Arde, collages de León Ferrari con las noticias publicadas por la prensa afín al régimen de Onganía, en los que se plasmaba una imagen de la situación de la provincia que contrastaba con el material resultante del trabajo interdisciplinar llevado a cabo por los artistas, 1968.

Para Carpani, el proceso de politización experimentado por los integrantes de $\mathrm{Tu}$ cumán Arde únicamente les había llevado a asumir una posición respecto a la articulación entre el arte y la política más próxima de lo que se pudiera pensar en un principio a las prácticas que el propio Carpani y los miembros del Movimiento Espartaco habían desarrollado desde finales de los años cincuenta. Para Carpani, fueron los «avatares de la historia» (como la revolución cubana o el Mayo francés) los que, al poner la revolución de moda, hicieron que la vanguardia artística se politizara desechando el arte para afirmar la «acción revolucionaria». Esta circunstancia explicaría que la vanguardia hubiese abandonado instituciones como el Di Tella para repensar su actividad en el contexto de un sindicato, un ámbito de movilización política que la práctica artístico-política de Carpani había transitado, en clave muy distinta, desde finales de los años cincuenta. Al afirmar provocativamente que la vanguardia había hecho lo mismo que él pero «diez años después», Carpani pretendía recuperar una biografía de compromiso artístico-político que se remontaba más allá de la emergencia de aquella ${ }^{2}$.

2 Cfr. A. LONGONI y M. MESTMAN, Del Di Tella a «Tucumán Arde». Vanguardia artística y politica en el 68 argentino. Buenos Aires, Eudeba, 2008, pág. 437. 
El Movimiento Espartaco fue uno de los primeros colectivos que reivindicó, desde finales de los años cincuenta, la necesidad de crear un arte de plausible raigambre latinoamericana. Además de Ricardo Carpani, la agrupación estaba integrada por Esperillo Bute, Pascual Di Bianco, Julia Elena Diz, Raúl Lara Torrez, Mario Mollari, Carlos Sessano y Juan Manuel Sánchez, a los que en 1965 se sumaría Franco Venturi, asesinado en 1976 por el Proceso Militar. El grupo apareció públicamente en 1959 durante la exposición de Arte Moderno Rioplatense en el Museo de Arte Moderno de Buenos Aires, un año después de que algunos de sus miembros publicaran en la revista Política el manifiesto «Por un arte revolucionario en América Latina», firmado por Mollari, Sánchez, Carpani, Diz y Bute ${ }^{3}$. El colectivo abogaba, frente al vanguardismo aperturista de las instituciones artísticas impulsadas por la Revolución Libertadora ${ }^{4}$, por la consolidación de un arte nacional que tuviese, entre otros referentes, al muralismo mejicano, cuya monumentalidad merecía la pena ser rescatada ${ }^{5}$. Estos artistas contemplaban con recelo la importación y asunción de las tendencias artísticas internacionales ajenas al espacio latinoamericano, pues éstas impondrían unas condiciones perniciosas de producción en relación a la realidad interna de los países que conformaban esa demarcación geopolítica. Una realidad sobre la que, por lo demás, se aspiraba a extender la pulsión revolucionaria que movilizaba a los integrantes del colectivo. Desde una óptica freudomarxista, sus integrantes invocaban en el manifiesto de 1959 titulado «Por un arte revolucionario» la relevancia política del arte a la hora de alentar-pero también de modelar- la liberación del inconsciente colectivo como tránsito hacia la emancipación de la sociedad en su conjunto ${ }^{6}$.

3 Los argumentos expuestos en ese manifiesto serían desarrollados en años posteriores por el propio CARPANI en las publicaciones Arte y revolución en América Latina (Buenos Aires, Coyoacán, 1961) y La política en el arte (Buenos Aires, Coyoacán, 1962). En el primero de ellos, Carpani se esforzó por definir la naturaleza de un arte que incorporara a un mismo tiempo los componentes nacional y latinoamericano como estrategia de resistencia ante el imperialismo cultural. Ese «arte nacional latinoamericano» debía acompañar a la revolución proletaria desmarcándose tanto de la influencia extranjerizante que Carpani asignaba a la pintura abstracta como de la «tergiversación burocrática» que el artista identificaba con el realismo socialista. En el segundo, la referencia a estas tendencias artísticas se veía mitigada a favor de un énfasis mayor en los modos de articulación entre la práctica artística, las organizaciones obreras y las experiencias revolucionarias.

4 Sobre el panorama artístico durante la Revolución Libertadora cfr. A. GIUNTA, Vanguardia, internacionalismo y política. Arte argentino en los años sesenta. Buenos Aires, Paidós, 2001, págs. 85-127.

5 No se trataba, por cierto, de la primera tentativa de reinventar el muralismo con un sentido adaptado a la idiosincrasia política y social argentinas. Esa había sido precisamente una aspiración de la Mutualidad Popular de Estudiantes y Artistas Plásticos de Rosario, liderada durante los años treinta por el pintor Antonio Berni. A comienzos de esa década «infame» visitó el país David Alfaro Siqueiros, quien, junto a Berni, Lino Enea Spilimbergo, Juan Carlos Castagnino y Enrique Lázaro recibió el encargo de realizar un mural de $200 \mathrm{~m}^{2}$ para el sótano de la residencia de Natalio Botana, cfr. J. López ANAYA, Ritos de fin de siglo. Arte argentino y vanguardia internacional. Buenos Aires, Emecé, 2003, págs. 37 y 340. Aunque la temática del mural no era explícitamente política, la visita de Siqueiros contribuyó a reanimar las esperanzas de los artistas argentinos; unas esperanzas que se desvanecieron con el paso de la década, hasta encontrar su abrupto final con el golpe militar de 1943 y la política impuesta por el general Pedro Pablo Ramírez, que proscribió el Partido Comunista, al que Berni vinculaba el despliegue de un nuevo arte público, cfr. Cristina ROSSI, «¿Adónde va la pintura? Dos respuestas de Antonio Berni frente a una misma pregunta», Discutir el canon. Tradiciones y valores en crisis. Buenos Aires, CAIA, 2003, págs. 462-463.

${ }^{6}$ Cfr. Grupo Espartaco, «Por un arte revolucionario», R. CIPPOLINI (ed.), Manifiestos argentinos. Políticas de lo visual 1900-2000. Buenos Aires, Adriana HIDALGO, 2003, pág. 287. 
El Movimiento, disuelto definitivamente en febrero de 1976, pero cuya actividad como grupo concluyó en realidad en 1968 con una exposición conjunta en la Galería Whitcomb, se desmembró progresivamente por el deseo de algunos de sus integrantes de acentuar su marginalidad respecto al ámbito institucional. Los primeros en desvincularse de él fueron Carpani y Di Bianco. Ambos abandonaron el colectivo en 1961 para ligarse de modo más activo a los sindicatos que, ante la proscripción electoral del peronismo tras la llegada al poder de la Revolución Libertadora, habían recogido su masa social. En esta decisión vislumbraban la posibilidad de concretar en la práctica el compromiso social expresado de modo propositivo por los manifiestos del grupo. Desde las páginas de Compañero, Carpani lanzó sus invectivas «tanto a las instituciones modernizadoras y a la vanguardia como a los artistas de la izquierda tradicional $\gg^{7}$. En su acerada crítica de las políticas culturales implementadas por el gobierno de Arturo Frondizi (1958-1962), Carpani cargaba contra el Instituto Di Tella, cuya actividad contribuía, en su opinión, a reforzar la imagen pública de la burguesía industrial nacional que lo patrocinaba, impidiendo de ese modo que el arte se implicara en una verdadera revolución social. Carpani, en cuyos escritos aparecen mencionadas las teorías marxistas de Henri Lefebvre, que también inspiraron a los situacionistas franceses, concretaría ese compromiso en la elaboración de carteles propagandísticos para el Cordobazo de mayo de 1969 (la huelga obrera más importante del período de la dictadura de Onganía), en su colaboración con la CGT de los Argentinos y en la creación de lienzos en los que glorificaba a héroes nacionales como Evita, Perón o el Ché Guevara (fig. 3) ${ }^{8}$.

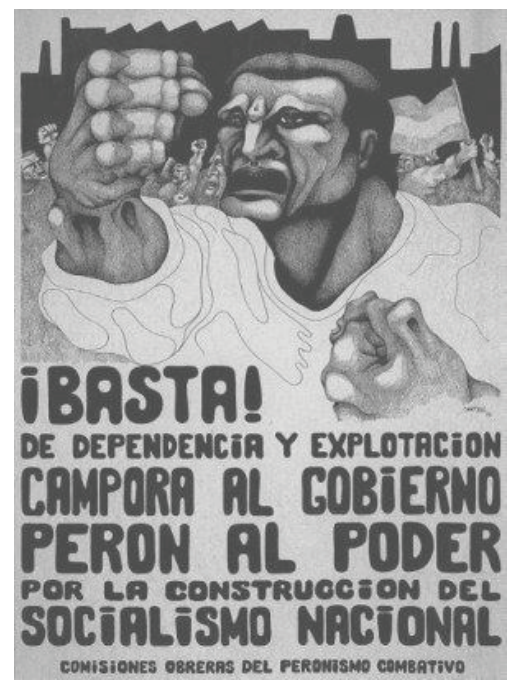

Fig. 3: Cartel diseñado por Ricardo Carpani en apoyo de la candidatura presidencial del peronista Héctor Cámpora, 1972.

\footnotetext{
7 A. LONGONI y M. MESTMAN, Del Di Tella a «Tucumán Arde». Vanguardia artística y política en el 68 argentino. Op. cit., pág. 83.

8 Cfr. Ana ALDABURU, «Ricardo Carpani», El grabado social y politico en la Argentina del siglo XX. La Plata, Instituto de Historia del Arte argentino y americano/ Facultad de Bellas Artes de la Universidad Nacional de La Plata, s. f., pág. 59.
} 


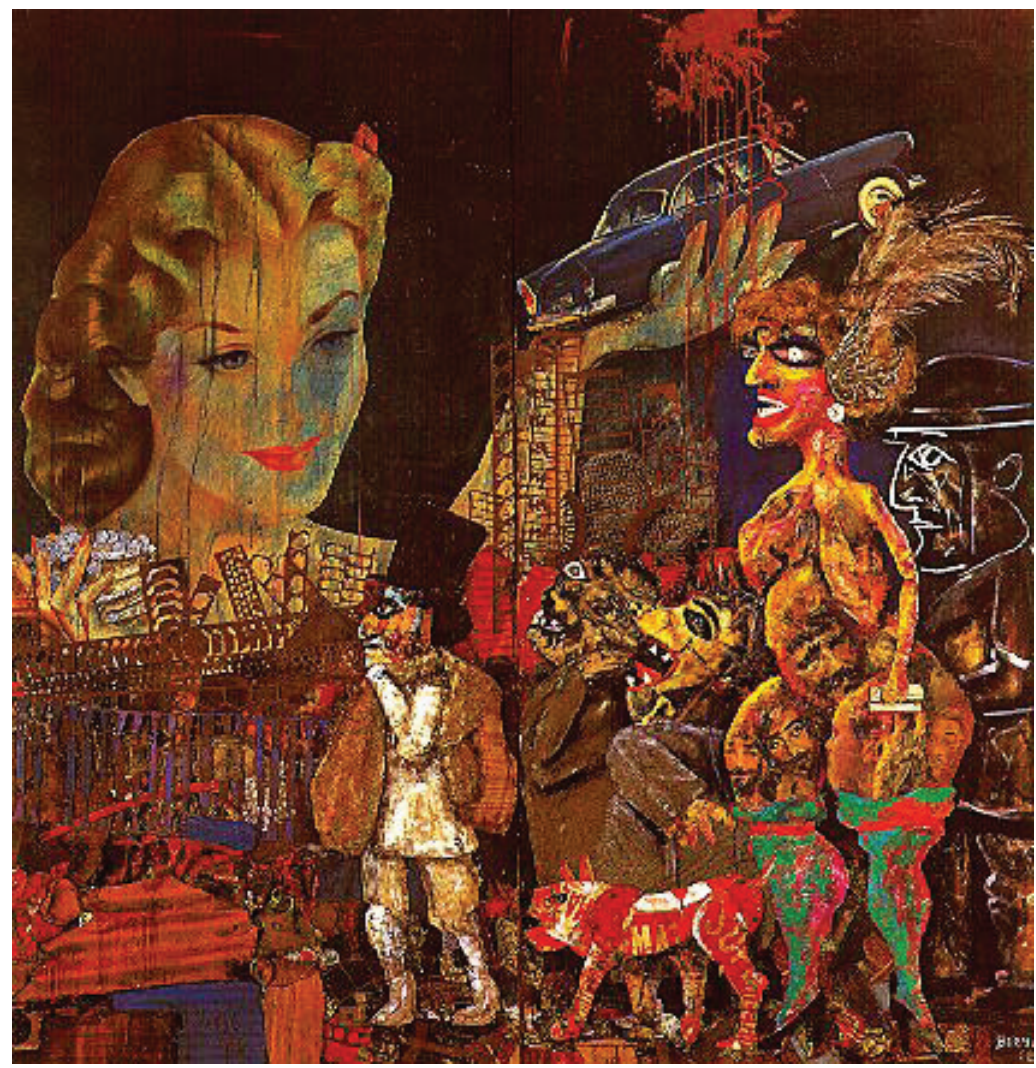

Fig. 4: Antonio Berni, una de las imágenes que componen la serie dedicada a Ramona Montiel, 1962.

El anti-vanguardismo de Carpani no impedía, sin embargo, que rechazara por igual prácticas en principio opuestas a la vanguardia, como el realismo socialista, al que identificaba con el curso burocrático del estado soviético. Esa postura le condujo a despreciar el arte de pintores que, como Antonio Berni, habían compartido expectativas políticas similares a las de Carpani. Éste tildaba de «miserables» las series de lienzos que Berni realizaba desde finales de la década de los cincuenta, pues en su opinión incitaban al sentimiento caritativo de la burguesía allí donde era necesario desplegar una práctica artística verdaderamente revolucionaria. Al hablar de Berni, Carpani probablemente tendría en mente representaciones de la pobreza como las series Juanito Laguna y Ramona Montiel, en las que el pintor argentino relataba, respectivamente, las vidas de un niño villero y de una prostituta, ambos personajes excluidos de la sociedad, residuos despreciables para la maquinaria del sistema (fig. 4). En las series, compuestas de grabados y óleos, la técnica del collage se ponía al servicio de una estética del reciclaje que otorgaba valor artístico a los restos de la sociedad industrial. Pese al localismo que acusaban ambas historias, las obras obtuvieron el premio de grabado en la Bienal Internacional de Venecia de 1962. La síntesis entre lo local y lo vanguardista con que se asociaba al gusto burgués se veía 


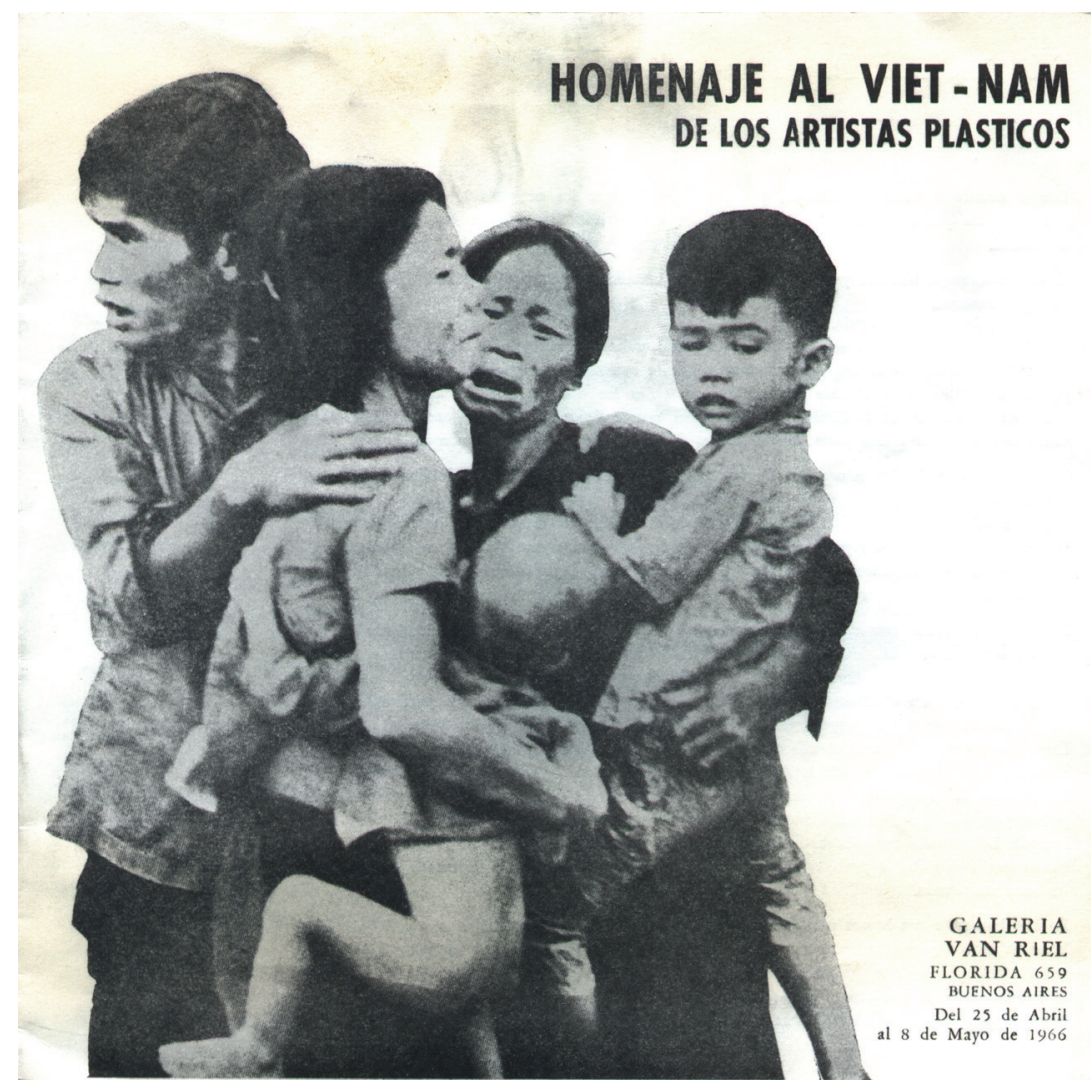

Fig. 5: Cartel del «Homenaje al Vietnam», Galería Van Riel, Buenos Aires, 1966.

así consagrada en la esfera internacional. Este hecho acabaría por exasperar a quienes, como Carpani, abogaban por el tránsito de la representación de la miseria a la activación revolucionaria del sujeto que la padecía. Para el artista argentino, lo que este tipo de imágenes mostraban eran las víctimas y penurias de un sistema que se mantenía entretanto intacto9.

Carpani vinculaba ese miserabilismo estético con los artistas de la órbita del Partido Comunista. En la Argentina de los años sesenta, artistas próximos al PC controlaban la SAAP (Sociedad de Artistas Plásticos) ${ }^{10}$. Sin embargo, la obra de estos artistas no siempre se encuadraba dentro de la vertiente socialista del realismo. Así sucedía, por ejemplo, con los lienzos de Carlos Gorriarena. Si el PC, alineado con Moscú, había mostrado diversas reticencias a los procesos de resistencia y revolución arma-

${ }^{9}$ Cfr. A. GIUNTA, «Cuerpos de la historia. Vanguardia, política y violencia en el arte argentino contemporáneo». Cantos paralelos. La parodia plástica en el arte argentino contemporáneo. Austin/ Buenos Aires, University of Texas/ Fondo Nacional de las Artes, 1999, pág. 144.

${ }^{10}$ Los integrantes de la vanguardia argentina de los años sesenta también habían mantenido distancia con esta organización, cuyos artistas eran tachados de reaccionarios estéticos por aquellos que cobraron visibilidad en torno al Instituto Di Tella y el circuito de galerías afín a su propugnación del experimentalismo artístico. 
das en Vietnam o Cuba, por no ajustarse a la ortodoxia de las condiciones objetivas y subjetivas, plataformas de discusión próximas ideológicamente a su ideario como la revista La Rosa Blindada cuestionaban ese tipo de interpretaciones de la historia reciente $^{11}$. Así, cuando Gorriarena, expulsado unos años antes del partido, se hacía eco de una de las experiencias artísticas colectivas más relevantes de la época, el «Homenaje al Vietnam», celebrado en la Galería Van Riel en 1966, subrayaba como rasgo distintivo de las nuevas generaciones «la actitud crítica de éstas a las fuerzas de izquierda tradicionales de nuestro país (...) paralela a su antiimperialismo y a su interés por las últimas experiencias revolucionarias internacionales» (fig. 5) ${ }^{12}$. Ese antiimperialismo venía refrendado por la firma de 220 artistas a los que se sumarían, tras la inauguración de la muestra, otros cincuenta. León Ferrari, engranaje fundamental en el proceso de «politización» de la vanguardia del Instituto Di Tella, ha insistido en diversas ocasiones en la relevancia que en ese proceso tuvo el encuentro propiciado por el «Homenaje al Vietnam» entre los integrantes de la vanguardia y la facción artística liderada por el propio Carpani. Para Ferrari, Carpani pasa por ser la «figura más destacada» del arte político argentino. Lo sería por haber tenido antes que nadie claro que el arte llega al pueblo no sólo «por lo que son sus imágenes, sino porque estaban donde debían estar, en los afiches, en la calle, en los sindicatos, en las revistas y publicaciones políticas» ${ }^{13}$.

En la muestra, la alusión a la guerra de Vietnam y a la invasión norteamericana de Santo Domingo como ejemplos de la racionalidad intrínseca a la civilización occidental remitía al título de la obra de León Ferrari con la que se suele relacionar el inicio del mencionado proceso de «politización» de la vanguardia argentina de los años sesenta. Nos referimos a La civilización occidental y cristiana, presentada en agosto de 1965 al Premio Nacional del Instituto Di Tella (fig. 6). «La civilización occidental y cristiana» era la cantinela que la burguesía argentina más conservadora esgrimía como síntoma de buena conducta, pero también la expresión del modelo civilizador que se deseaba extender al Lejano Oriente. La obra constaba de un Cristo de santería con el cuerpo magullado y sangrante, crucificado sobre una réplica en miniatura del avión americano modelo FH-107, empleado por entonces en la guerra de Vietnam. Jorge Romero Brest, director del Instituto, con antelación a la inauguración de la muestra y alegando diversas razones de índole religiosa y oportunismo político, sugirió a Ferrari la retirada de la pieza a cambio de que sí pudiesen ser exhibidas las otras tres que el artista presentaba, todas ellas dispuestas en cajas y con una temática similar a la obra censurada. La primera de ellas hacía referencia al bombardeo de una escuela vietnamita. La segunda constaba de un crucifijo con un esqueleto en lugar de Cristo acompañado de recortes de prensa relativos al conflicto bélico. Finalmente, la tercera de las piezas, compuesta por el despliegue de catorce aviones de combate, alu-

\footnotetext{
11 Esto llevaría al progresivo alejamiento del Partido Comunista del núcleo de intelectuales que trabajaron en la revista. María Teresa Constantín señala que este proceso afectó, además de al propio Gorriarena, a Carlos Broccatto, José Luis Mangieri, Juan Gelman, Andrés Rivera, Roberto Cossa y Octavio Gettino, cfr. M. Teresa Constantín, Cuerpo y materia. Arte argentino entre 1976 y 1985. Buenos Aires, Fundación Osde, 2006.

12 C. GORRIARENA, «Salón homenaje al Vietnam», Néstor Cohan (ed.), La Rosa Blindada. Una pasión de los '60. Buenos Aires, La Rosa Blindada, 1999, pág. 328.

13 A. LONGONI y M. MESTMAN, Del Di Tella a «Tucumán Arde». Vanguardia artística y política en el 68 argentino. Op. cit., pág. 341.
} 


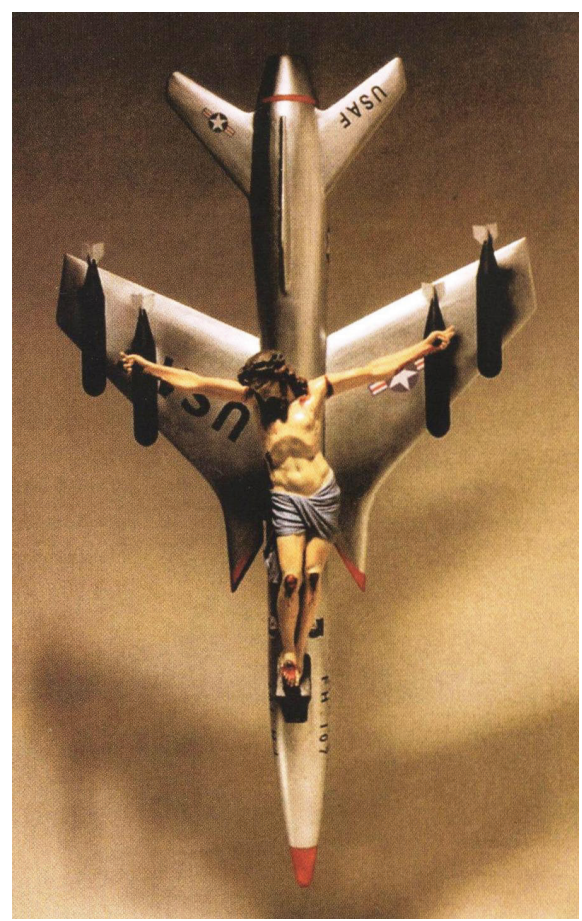

Fig. 6: León Ferrari, La civilización occidental y cristiana, 1965.

día al número de votos mediante los cuales la OEA (Organización de Estados Americanos) había avalado la intervención norteamericana en la República Dominicana.

Esta última obra poseía una dimensión coyuntural muy marcada. Tras el golpe de Estado en Brasil en 1964, el impulso desarrollista al que aspiraban numerosos países latinoamericanos pasó de modo sucesivo a manos de dictaduras que contaron con el apoyo o el beneplácito de los Estados Unidos, cuya prioridad era contener cualquier brote revolucionario en la zona, especialmente tras lo sucedido en Cuba a finales de los años cincuenta. La «Alianza para el Progreso», iniciativa impulsada por una misiva enviada en 1958 por el presidente brasileño Juscelino Kubitschek a Eisenhower, fue posteriormente auspiciada por John F. Kennedy. Durante su mandato se celebró en Punta del Este (Uruguay), entre el 5 y el 17 de agosto de 1961, la reunión del Consejo Interamericano Económico y Social de la OEA (Organización de Estados Americanos). De aquel encuentro salieron una Declaración y una Carta que fueron firmados por todos los países de la organización (diecinueve) salvo Cuba. En los años posteriores los presidentes argentinos afrontarían diversas dudas en torno a cómo posicionarse a la hora de tomar decisiones en el seno de la alianza. Así, en febrero de 1962 el presidente Arturo Frondizi se mostró en contra de expulsar a Cuba de la OEA. Más tarde, durante el mes de mayo de 1965, se produjeron en toda Argentina manifestaciones que, organizadas por la CGT (Confederación General del Trabajo, principal sindicato del país, de orientación peronista) y la Federación Universitaria, 
mostraban su repulsa al envío de tropas argentinas al país dominicano. Esta reclamación, que acabó por acatar el presidente Arturo Illía, acentuó el malestar de la cúpula militar, que retiró su apoyo a Illía ante la decisión adoptada y comenzó a planear el golpe de Estado del año siguiente.

Tras la censura de su obra, Ferrari replicó elocuentemente a Romero Brest al publicar en el periódico Propósitos, el 7 de octubre de ese mismo año, una declaración que, en su desdén por el valor formal del arte, prefiguraba la disolución de la vanguardia cultural (avant-garde) en la vanguardia política (vanguard), que culminaría dos años después con el mencionado abandono de las instituciones culturales de la burguesía nacional y el desplazamiento de la actividad artística al ámbito sindical de la mano de la experiencia Tucumán Arde, en la se se involucraría el propio Ferrari:

Ignoro el valor formal de esas piezas. Lo único que le pido al arte es que me ayude a decir lo que pienso con la mayor claridad posible, a inventar los signos artísticos y críticos que me permitan con la mayor eficacia condenar la barbarie de Occidente; es posible que alguien me demuestre que esto no es arte: no tendría ningún problema; tacharía arte y lo llamaría política, crítica corrosiva, cualquier cosa ${ }^{14}$.

El «Homenaje al Vietnam» marcó el punto de intersección entre los presupuestos que guiaban la actividad artístico-política de Ricardo Carpani y León Ferrari. Ese punto de intersección coincidiría, a grandes rasgos, con un rechazo tanto de la ortodoxia del realismo socialista como de la impotencia revolucionaria de la forma vanguardista. Se trataba, por otra parte, de afirmar el desplazamiento de la centralidad del arte desde la reflexión formal a la efectividad del mensaje político, de la vanguardia cultural a la vanguardia política, una posición que cuando las organizaciones políticas y armadas asumieron la delantera de esta última vanguardia, situó en un lugar delicado a la producción visual de los artistas afines ideológicamente a ellas. El sentido histórico de la nueva idea del arte propugnada por Ferrari se relacionaba directamente con una reflexión en torno al estatuto del artista en el proceso revolucionario ${ }^{15}$.

El lugar del artista y su relación con un nuevo público fue un debate crucial en el arte argentino y latinoamericano posterior a la revolución cubana. Con el final de la década de los sesenta y el principio de los setenta, la figura del intelectual como conciencia crítica iba a dejar paso a la del intelectual revolucionario. Ya no se trataba solo de realizar una crítica social desde el lugar que le había sido designado al artista o al escritor en la esfera cultural, ni de reducirse a producir formas de representación de la realidad que concienciaran a la sociedad sobre la lógica de la dominación. El intelectual revolucionario debía involucrarse ahora más decididamente en el proceso de transformación de lo social, de manera que incentivara la movilización colectiva en torno a las organizaciones de la vanguardia política ${ }^{16}$. Si bien es cierto que ese

14 Cfr. A. LONGONI y M. MESTMAN, Del Di Tella a «Tucumán Arde». Vanguardia artística y politica en el 68 argentino. Op. cit., pág. 89.

15 Para un estudio de la repercusión en el campo literario de ese acontecimiento cfr. Claudia GILMAN, Entre la pluma y el fusil. Debates y dilemas del escritor revolucionario en América Latina. Buenos Aires, Siglo XXI, 2003.

16 Por decirlo con Néstor García Canclini, a estos artistas «más que reproducir la realidad les interesaba imaginar los actos que la superaran», N. GARCÍA CANCLINI, Arte popular y sociedad en América Latina; estéticas y ensayos de transformación. México D.F., Grijalbo, 1977, págs. 49-51. 
proceso alumbró experiencias tan singulares como Tucumán Arde, también condujo en los años inmediatamente posteriores a la conclusión de esa experiencia a que, en ocasiones, la práctica artística se viera supeditada a los mandatos de la vanguardia política, estrechando de ese modo el campo de la experimentación ${ }^{17}$.

La pretensión de incidir directamente sobre la realidad social y política cobrará en ocasiones un carácter conativo que ya había sido previsto por artistas como Roberto Jacoby cuando pronosticaba en la década de los sesenta que «no se tratará ya, seguramente de expresar las emociones del artista ni de «mostrar la realidad» sino de actuar sobre el receptor, de «hacer hacer»»» ${ }^{18}$. Este deseo de «hacer hacer» se desplegará en un contexto histórico en el que la política fue progresivamente reducida a la revolución, de manera que ésta, lejos de resquebrajar, según había pronosticado Roland Barthes, la apariencia y consistencia ideológicas del mito, devenía mito a su $v z^{19}$. La historia de la revolución como narración mítica se vería apuntalada en la Latinoamérica de los sesenta-setenta por la creciente influencia de la teoría del foco ${ }^{20}$ y, en el caso concreto argentino, por la expectativa del regreso o la venida de Perón, exiliado por entonces en España, en el que un amplio sector de las organizaciones revolucionarias depositaban sus esperanzas de cambio.

La conversión del artista en una suerte de socio-ideólogo, de la que Tucumán Arde es la experiencia más audaz, le situaba con frecuencia en una posición mesiánica que reproducía en el campo (desplazado) del arte el dirigismo revolucionario que asomaba ya hacia finales de los sesenta en algunos de los documentos de circulación interna de las incipientes organizaciones guerrilleras, cuya exaltación de la violencia se infiltró en la literatura artística del período. Así, a propósito de la concepción de la lucha armada en el imaginario de las FAL (Fuerzas Armadas de Liberación, de tendencia peronista), Gabriel Rot relata que la organización justificaba las acciones violentas que sus miembros habrían de emprender contra la burguesía en tanto que solo de ese modo el «espontaneísmo» que atribuían a movilizaciones sociales como la que se produjo con motivo del Cordobazo podría evolucionar hacia un «estadio superior de confrontación». Según señala Rot, organizaciones como las FAL, ante la carencia «de

\footnotetext{
17 Este último aspecto fue enfatizado por Beatriz SARLO, La máquina cultural. Maestras, traductores y vanguardistas. Buenos Aires, Planeta, 1998, pág. 253.

18 R. JACOBY, «Contra el happening», I. KATZENSTEIN (ed.), Escritos de vanguardia. Arte argentino de los años '60. Nueva York/ Buenos Aires, MOMA/Fundación Proa/ Fundación Espigas, 2007, pág. 240.

19 Este apunte parece confirmar el juicio de Boris Groys cuando señalaba que «(...) La contraposición barthesiana entre el mito y el hacer, o transformar, el mundo asombra ya por contradecir el hecho evidente de que todos los mitos importantes que conocemos narran precisamente la creación del mundo y sus transformaciones: el mundo inmóvil, no cambiante, ahistórico, no puede ser contado en un mito (...) si el mito, a pesar de lo que escribe Barthes, tiene que ver con la creación y transformación del mundo, entonces son precisamente la vanguardia y la política de izquierda, en primer término, las que resultan mitológicas, porque al colocar al artista, al proletariado, al Partido, al líder, en el papel de demiurgo, los integra con gran naturalidad en la mitología mundial», B. GROYS, Obra de arte total Stalin. Valencia, Pre-textos, 2008, págs. 217-8.

20 Término enunciado por Ernesto «Ché» Guevara y Regis Debray para designar la fundación de pequeños focos de resistencia guerrillera de corta duración. Esta teoría desechaba la necesidad de que a la revolución debiera antecederla la determinación de unas condiciones objetivas y subjetivas para su consumación. Esa era, en opinión de Guevara, una de las «aportaciones fundamentales» de la Revolución Cubana. Guevara formuló esta teoría en sus «Principios generales de la lucha guerrillera», Ernesto CHÉ GUEVARA, Escritos revolucionarios. Barcelona, Los Libros de la Catarata, 2010, pág. 31-32.
} 
relaciones orgánicas con los movimientos sociales, entendieron este paso a través del enfrentamiento armado llevado a cabo por grupos tutelares, a los que le otorgaban el rédito de representar la vanguardia armada de la clase» ${ }^{21}$.

Si bien es cierto que otras organizaciones vinculadas a la lucha armada trataron de paliar con el paso del tiempo esa carencia de «relaciones orgánicas con los movimientos sociales» y los sindicatos mediante el trabajo de superficie en barrios y fábricas, el texto que acabamos de mencionar evidencia la problemática ligada a la confrontación de las construcciones ideológicas con la realidad a la que interpelan y con la que no dejan de formar un mismo plano. Tales construcciones respondían a una idea dorsal de la época, según la cual la acción armada, a partir del éxito cubano, se presentaba como el medio que podía y debía crear las condiciones subjetivas para la revolución más allá de que estas se dieran de modo objetivo en un contexto determinado. La cita anterior es una muestra de las fricciones dentro de los diferentes sectores de la izquierda, constituyendo un claro indicio de cierta asincronía entre la lógica revolucionaria de la guerrilla -que en su vanguardismo se otorgaba el derecho de definir la evolución de la lucha- y la lógica insurreccional (aquí tachada de meramente espontaneísta) del movimiento proletario. La organizaciones revolucionarias obviaron, en el transcurso de esos años, el efecto de división que generó en el campo social la retórica armada, el cual acabó por predominar sobre su intento de constituirse como catalizador de energías ${ }^{22}$. El desprecio generalizado de la democracia como una salida viable para las aspiraciones emancipatorias, sin duda alentado por la historia reciente del país, fue también una constante de la época. La toma del Estado como estadio último del proceso revolucionario respondía a una lógica que nuevamente encontraba su fuente de inspiración en el caso cubano. Una lógica estadocéntrica que comprometía la posibilidad de dar cuerpo a una política de organización social que se situara al margen de esas proyecciones finalistas. Las hipotecas derivadas de la afirmación identitaria en clave estrictamente antiimperialista -que no dejó de afectar, por lo demás, a las prácticas artísticas- contribuían a consolidar esa carencia y a impedir dar forma a un proyecto político colectivo ${ }^{23}$.

Si trasladamos algunas de estas reflexiones al campo del arte, resulta difícil trazar el límite entre la posibilidad de pensar experiencias como Tucumán Arde como estrategias de subjetivación que perseguían actualizar potencialidades revolucionarias o, en el lado negativo, como formas de jerarquización que objetualizaban al espectador;

\footnotetext{
${ }^{21}$ ROT Señala como principal objetivo de las FAL el «desgaste indirecto de la burguesía» que «haría «sentir a la patronal y a la dictadura el rigor de la violencia proletaria organizada», contribuyendo a desencadenar el enfrentamiento de clases en forma abierta. G. ROT, «Notas para una historia de la lucha armada en la Argentina. Las Fuerzas Argentinas de Liberación», Políticas de la Memoria, CeDInCI, nº 4, verano 2003/04, pág 154.

${ }_{22}$ Cfr. U. GORINI, La rebelión de las Madres. Historia de las Madres de Plaza de Mayo. Tomo I (19761983). Buenos Aires, Norma, 2006, pág. 54.

23 Pilar CALVEIRO, quien fuera militante de Montoneros, la principal guerrilla peronista durante los años setenta, y detenida-desaparecida por el Proceso militar, es muy contundente en su análisis retrospectivo de este hecho: «(...) no se profundizaba en el proyecto de nación que se pretendía, más allá de la reafirmación antiimperialista y anticapitalista. De hecho, se postergaba la discusión de qué revolución se pretendía por el debate sobre cómo lograr tomar el aparato del Estado, llave mágica que abriría las puertas del cambio». P. CALVEIRO, «Antiguos y nuevos sentidos de la política y la violencia», Lucha armada en la Argentina, año I, 4, septiembre-noviembre de 2005, pág. 10.
} 
una estructura comunicativa en la que el intelectual se posicionaba como «vocero de la Revolución». Óscar Terán señaló la relevancia que acontecimientos como «La noche de los bastones largos» (29 de julio de 1966), la violenta intervención policial mediante la cual la dictadura de Onganía había tratado de poner fin a la autonomía universitaria, y el propio Cordobazo tuvieron en la configuración de esta subjetividad del intelectual:

ahora era posible hallar (o creer hallar) referentes privilegiados capaces de corporizar en la sociedad la protesta que el intelectual entonaba desde su propia práctica. Así, a la pregunta por aquello que legitimaba el quehacer intelectual, se respondió que su fundamento residia en su capacidad para constituirse en vocero del Pueblo y de la Clase Obrera, en vocero de la Revolución (...) El Cordobazo permitió luego iluminar con el fulgor de un relámpago la tierra prometida del Hombre Nuevo. Se iniciaba así un sendero en donde el deslumbramiento por la política terminaría por devorar la autonomía intelectual ${ }^{24}$.

En oposición a esta pervivencia de un arte político representativo de los intereses del pueblo y como concreción de esa pérdida de autonomía del intelectual de la que hablaba Terán, un nuevo planteamiento surgió en los años setenta. A modo de corrección ideológica de lo que había sido la formación del intelectual argentino durante la década anterior, los documentos conservados de los encuentros de artistas latinoamericanos celebrados durante los primeros años de la década de los setenta en Santiago de Chile y La Habana dan cuenta del paso de un «arte revolucionario» a un «arte socialista» ${ }^{25}$. Si experiencias como Tucumán Arde, incluso pese a su búsqueda de un nuevo público, no escaparían al primero de esos estadios, el segundo de ellos reflejaría la verdadera «cultura del pueblo» ${ }^{26}$. Una cultura que acabaría con las convenciones burguesas en torno al arte y con toda autoridad de las figuras del artista o del intelectual. Este tránsito ha sido tematizado por Claudia Gilman en su análisis del campo literario latinoamericano de los sesenta-setenta en los siguientes términos:

Si la sociedad como público había sido una aspiración ferviente a comienzos de la época, lo que se produjo entonces fue la radicalización de la exigencia para la cual cultura es un espacio social si y solo si el conjunto de la sociedad fuera capaz de producirla ${ }^{27}$.

24 Ó. TERÁN, «Intelectuales y política en Argentina», Le Monde diplomatique, año IV, 41, noviembre de 2002, pág. 34.

25 Entre otros, la «Declaración de La Habana» (26 de julio de 1971), los informes de las diferentes comisiones que se constituyeron durante el Encuentro de Artistas Plásticos del Cono Sur (mayo de 1972), el «Llamamiento a los Artistas Plásticos Latinoamericanos» (también de mayo de 1972) o la «Declaración» que siguió al Encuentro de Plástica Latinoamericana celebrado en la Casa de las Américas de la Habana (octubre de 1973). Todos estos documentos se hallan en el Archivo Graciela Carnevale.

26 Así, por ejemplo, en la «Declaración de La Habana» de 1971 se apostaba, en oposición al modelo burgués, «por un arte que sea expresión de las necesidades de un pueblo de definirse como cultura y que signifique un reencuentro del artista con el pueblo». Archivo Graciela Carnevale.

27 C. GILMAN, Entre la pluma y el fusil. Debates y dilemas del escritor revolucionario en América Latina. Op. cit., pág. 177. 
Este punto de vista abonará un creciente antiintelectualismo, generalizado ya hacia los años setenta, en el que el artista en particular y el intelectual en general se cuestionarán el carácter ético de su existencia social como entidades separadas y reconocibles $^{28}$. La tensión, típicamente moderna, entre el intelectual crítico y su transformación en activista social debía ser resuelta radicalmente en favor de esta última opción. Los «saberes y destrezas específicas» del intelectual ilustrado debían ser puestos, en primera instancia, al servicio de los organizaciones revolucionarias y, en última, socializados hasta diluir su figura en una «obra común». La autonomía que confería a los juicios del intelectual una pretensión de universalidad ya no tenía validez en un decurso histórico que exigía la verificación de esos juicios en una práctica revolucionaria que deshacía la inmovilidad del mundo sobre el que eran vertidos. Esta nueva concepción del artista en el proceso revolucionario se desplegó en un contexto en el que la izquierda requería consensuar, al menos en el plano teórico, una posición común que estrechó el margen de libertad en las metodologías artísticas de producción y en la generación de disensos estéticos. Relegada a las prescripciones ideológicas del discurso revolucionario, las discusiones entre artistas e intelectuales adquirieron un tono de concilio político, que no acabó de verse alterado por las rupturas derivadas del caso Padilla ni por la alternativa chilena, que trataba de implantar un régimen socialista tras llegar democráticamente al poder ${ }^{29}$.

Estas y otras cuestiones aparecen ejemplificadas en los escritos que León Ferrari y Ricardo Carpani redactaron con ocasión del Encuentro de Artistas Plásticos del Cono Sur, celebrado en el Instituto de Arte Latinoamericano de la Facultad de Bellas Artes de la Universidad de Chile en 1972. En su texto «El arte en América Latina», Ferrari resaltaba la omnipotencia de la burguesía para neutralizar la radicalidad crítica de las propuestas que acogía en el seno de sus instituciones ${ }^{30}$. Para Ferrari, la representación artística de la política era solo un síntoma más del paternalismo del artista

28 GILMAN subraya los vínculos entre antiintelectualismo y antivanguardismo cultural en Ibid., págs. 29-30, 162 y 335. En consonancia con Gilman, Terán también vinculaba este proceso a la influencia de la revolución cubana: «Una revolución nacida sin teoría (...) reactivó viejos resortes antiintelectualistas, desplazando el eje de las prácticas intelectuales hacia las específicamente políticas». Gilman va incluso más allá al afirmar que esos «viejos resortes» representaban uno de los elementos más característicos de la historia de la intelectualidad latinoamericana.

29 Buena muestra de ello fue el encuentro de artistas y críticos de arte (entre ellos, Mario Pedrosa, Aldo Pellegrini o Miguel Rojas Mix), celebrado en el Instituto de Arte Latinoamericano de Santiago de Chile en 1971. Los debates, grabados por Gaspar Galaz, fueron publicados en VV. AA., Cuadernos de la Escuela de Arte. Santiago de Chile, Pontificia Universidad Católica de Chile, 1997.

30 Para FERRARI, la libertad en el arte (burgués) era deudora de su falta de función social. En una línea que recuerda a los argumentos que Carpani había esgrimido durante la década anterior contra la pintura de Antonio Berni, afirmaba: «La libertad en el arte, que suele ser uno de los últimos reductos de la libertad en los liberalismos latinoamericanos, es afianzada por la burguesía permitiendo y hasta promocionando obras que la atacan pero que, al ser oficialmente admitidas y aplaudidas se transforman en señaladores de la tolerancia del régimen, en falsos indicadores de una libertad que sólo existe para que los artistas pinten cuadros pero no para que el pueblo tenga similares derechos. Los artistas tienen entonces derecho, y son aplaudidos por ello, a pintar hermosos cuadros sobre las Villas Miseria o sobre el hambre, pero quienes el hambre sufren no pueden hacer una manifestación en Buenos Aires porque el ejército ocupa la ciudad con sus tanques y tropas. El arte en esos casos es un deformador de la realidad, la crítica «artística» al sistema pasa a ser complicidad y la Villa Miseria pintada hace el mismo papel que una manzana usada para una naturaleza muerta. Estas obras no son políticas: solo usan la política para hacer arte, muy distintas por cierto de aquellas que usan el arte para hacer política». L. FERRARI, «El arte en América Latina», 1972, mimeografiado s.p. Archivo Graciela Carnevale. 
burgués que, progresista o reaccionario, se sentía con «el derecho de «concientizar (sic) a las masası»». Esto suponía, en opinión del propio Ferrari, la paralización de «todo desarrollo de un arte socialista» ${ }^{31}$. Las numerosas anotaciones que Ferrari incluyó en el documento mecanografiado original dan cuenta de sus vacilaciones a la hora de considerar cuál sería su lugar en ese proyecto. Estos titubeos oscilan entre la disolución del rol diferenciado del artista y su desempeño como colaborador con el pueblo. Resulta sintomático comprobar cómo, tras examinar las distintas formas de lucha que el artista debía adoptar en los distintos contextos (el del arte de elite, el de la enseñanza, el del medio popular), en un primer instante Ferrari escribiera que el verdadero arte revolucionario debía «ser hecho por el pueblo» para posteriormente añadir «con y por el pueblo» ${ }^{32}$.

Más compleja y estructurada resultaba la argumentación presentada por Ricardo Carpani al mismo encuentro. El paternalismo cultural denunciado por Ferrari fue también allí objeto de reflexión. Para superarlo Carpani abogaba por la «inserción real y efectiva» del artista en las luchas sociales de la clase obrera, «produciendo desde ella y para ella en función de sus necesidades y objetivos políticos liberadores ${ }^{33}$. Esta producción «desde abajo» era la única opción válida a la hora de generar «una expresión artística descolonizada». La interacción con las masas destinatarias del mensaje dependía de que el artista se desvinculara de su rol tradicional en la producción artística burguesa, siguiendo un itinerario pautado por los siguientes momentos: el primero de ellos se caracterizaría por el rechazo de «los moldes estéticos vigentes» y la elaboración de «una expresión artística nacionalmente diferenciada y necesariamente de contenido revolucionario social» ${ }^{34}$. Un segundo momento llevaría al artista a buscar un público masivo (la clase obrera, el pueblo) que contrastara con el elitismo para iniciados característico de las expresiones artísticas burguesas. El tercer momento consistiría en la eliminación de cualquier rasgo subjetivo que impusiera sobre ese destinatario potencial de las imágenes formas de representación en las que no se reconociera ${ }^{35}$. Estas formas de representación no hacían sino perpetuar «un concepto paternalista y de superioridad, que lleva [al artista] a enfocar su acción plásticopolítica como una gracia que concede a los trabajadores en lucha, visualizándolos como meros receptores pasivos de su mensaje» ${ }^{36}$. En contraposición, la inserción de los artistas en el corazón de las luchas populares -que Carpani identificaba con la clase obrera y «sus organizaciones revolucionarias realmente representativas» ${ }^{37}$ -

\footnotetext{
31 Ibid.

32 Ibid.

33 R. CARPANI, «Apuntes para una discusión sobre el papel del arte en América Latina. $3^{\mathrm{a}}$ parte. Una propuesta concreta: talleres de militancia plástica de bases», 1972, mimeografiado pág. 1. Archivo Graciela Carnevale.

34 Ibid., pág. 3.

35 Este tercer momento era coherente con la apostilla que Carpani introducía a la descripción del segundo de ellos: «Conserva, sin embargo, la concepción elitista de su actividad, concebida como elaboración individual de imágenes desde fuera de las necesidades y apetencias concretas de las masas, que se reconocen en ellas». Ibid., pág. 4.

36 Ibid., pág. 4.

37 R. CARPANI, «Apuntes para una discusión sobre el papel del arte en América Latina. $2^{\mathrm{a}}$ parte. Arte nacional y militancia revolucionaria en América Latina», 1972, mimeografiado pág. 6. Archivo Graciela Carnevale,
} 
le procuraría una visión más objetiva de sus necesidades revolucionarias. El artista pondría a disposición de aquellas sus facultades relativas a las producción de imaginario, pasando a ser un «mero objetivador en imágenes de esa cultura colectivamente elaborada por las masas $\rangle^{38}$. Finalmente, un cuarto momento consistiría en eliminar cualquier rastro de distinción social del artista, último reducto del privilegio cultural que Carpani vinculaba a la injerencia imperialista y colonizadora ${ }^{39}$.

El «verticalismo paternalista de las elites burguesas y pequeñoburguesas» debía ser así relegado, favoreciendo una verdadera socialización del arte que habilitara la capacidad creativa de la clase oprimida ${ }^{40}$. Era necesario que los medios de producción del imaginario quedaran en manos de los trabajadores, pues ello permitiría que éstos pudieran autorrepresentarse. Este planteamiento, contrapunto de las estrategias de representación desplegadas por el itinerario del 68, más próximas a una visión compasiva de las víctimas, perseguía constituir a las masas en agentes operativos del cambio social. Se propugnaba así un arte elaborado «con el pueblo y desde el pueblo» a partir de la constitución de talleres de militancia plástica de bases. Una concepción del arte que, sin embargo, no debía conducirlos a convertirse en un «mero y vacuo panfleto propagandístico» ${ }^{41}$.

En un libro publicado unos años más tarde, la necesidad de disolver la figura del artista moderno (o burgués) llevó nuevamente a Carpani a identificar el destino del arte con una visión humanista de la revolución ${ }^{42}$. No era el único que pensaba de este modo. Otro de los artistas asistentes al Encuentro de Artistas Plásticos del Cono Sur celebrado en Santiago de Chile en 1972, el pintor argentino Luis Felipe Noé, mantenía una postura similar en el «autorreportaje» que seguía a la publicación de

38 R. CARPANI, «Apuntes para una discusión sobre el papel del arte en América Latina. $2^{\mathrm{a}}$ parte. Arte nacional y militancia revolucionaria en América Latina», 1972, mimeografiado pág. 6. Archivo Graciela Carnevale,

39 Llevando hasta sus últimas consecuencias esta lógica derivada de una «necesidad de superación», Carpani se preguntaba: «¿Por qué si son las masas quienes cotidianamente elaboran con su lucha política descolonizadora nuestra cultura nacional, no habrán de ser ellas mismas las encargadas de objetivar en imágenes esa, su cultura? ¿Por qué dicha tarea debe necesariamente correr por cuenta exclusiva de especialistas (los artistas) formados como tales al margen de ese proceso en las colonizadas academias y círculos del propio sistema que las masas con su lucha intentan destruir y superar?» Ibid., págs. 5-6. Más adelante subraya la necesidad de «comenzar a generar las instancias de base que permitan a las masas ir objetivando ellas mismas (...) su propia cultura, en nuevas imágenes depuradas de todo vestigio elitista y, por lo tanto, colonizado». Ibid., pág. 6.

$40 \mathrm{Ibid}$., pág. 7. Este texto de CARPANI, que durante los años setenta tuvo una circulación muy restringida, servirá sin embargo de inspiración a Néstor GARCÍA CANCLINI para formular en la segunda mitad de la década de los setenta un modelo socializador del arte político que, en opinión del intelectual argentino, debía complementar los hallazgos alcanzados por el modelo sociológico implementado por experiencias como Tucumán Arde o el teatro villero practicado por el Grupo Octubre, cfr. N. GARCÍA CANCLINI, Arte popular y sociedad en América Latina. México D.F., Grijalbo, 1977, págs. 205 y ss. y, muy especialmente, N. GARCÍA CANCLINI, «La participación social del arte: el porvenir de una ilusión», Hueso Húmero, Lima, 5-6, abrilseptiembre de 1980, págs. 70 y ss. Ese modelo socializador se concretaría en la década de los ochenta en el arte político latinoamericano de un modo imprevisto por los escritos tanto de Carpani como de Canclini.

41 R. CARPANI, «Apuntes para una discusión sobre el papel del arte en América Latina. $2^{\mathrm{a}}$ parte. Arte nacional y militancia revolucionaria en América Latina», Op. cit., pág. 10. Archivo Graciela Carnevale.

$42 «(. .$.$) el destino del arte se halla identificado con el destino de la revolución, que es como decir con el$ destino de la humanización real del hombre, humanización de la cual el arte es, precisamente, la más completa expresión». R. CARPANI, Arte y militancia. Madrid, Zero, 1975, pág. 11. 


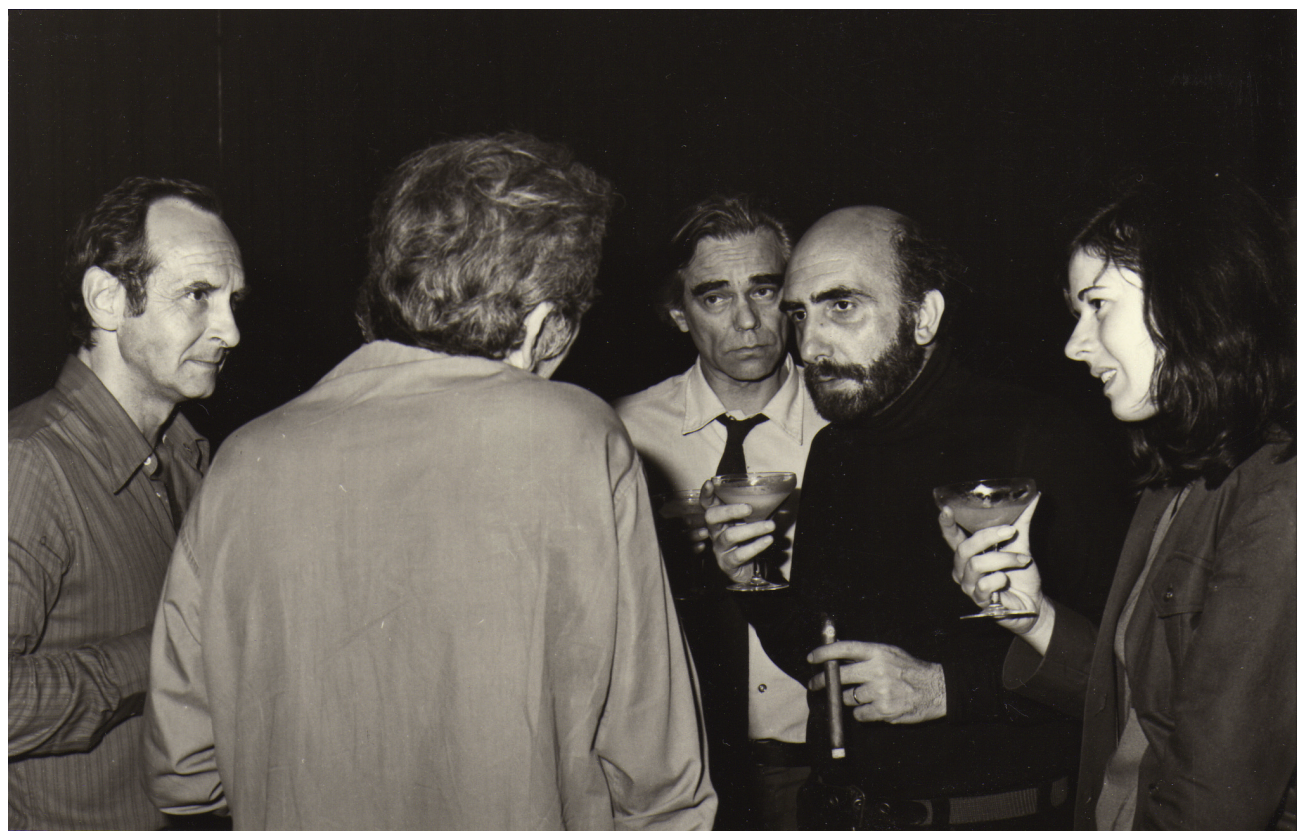

Fig. 7: Ricardo Carpani, León Ferrari y Luis Felipe Noé en el «Encuentro para una Nueva Plástica», La Habana, 1972.

una entrevista concedida a Miguel Rojas Mix, director del Instituto de Arte Latinoamericano de la Universidad de Chile e impulsor del mencionado encuentro (fig. 7). El título del «autorreportaje» explicitaba esta concepción del arte desde su mismo título: «El arte de América Latina es la revolución» ${ }^{43}$. A diferencia de Carpani, Noé se despegaba de cualquier consideración de la revolución que se engarzara con el pensamiento humanista, al que identificaba con el universalismo paralizante de la herencia filosófica burguesa ${ }^{44}$. A continuación, Noé aludía a la teoría de la dependencia para apuntalar su posición ${ }^{45}$. Desde su perspectiva, el desarrollismo económico y cultural implementado por los gobiernos latinoamericanos durante los años cincuenta sólo podía ser contemplado como un intento de adecuación a los dictámenes del imperialismo norteamericano que escondía tras su buena voluntad una ideología regresiva ${ }^{46}$.

43 M. ROJAS MIX (ed.), Luis Felipe Noé. El arte de América Latina es la revolución. Santiago de Chile, Andrés Bello, 1973.

44 Ibid., pág. 22.

$45 \mathrm{La}$ teoría de la dependencia, elaborada por diversos economistas y sociólogos marxistas de América Latina (Theotonio Dos Santos, Andre Gunder Frank, Ruy Mauro Marini, Celso Furtado, Enzo Faletto, Fernando Henrique Cardoso) entre los años cincuenta y setenta del pasado siglo, cifraba en el binomio centroperiferia las relaciones de poder económico que los países desarrollados mantenían con los no-desarrollados y daba cuenta del modo en que tales relaciones se reproducían en el interior de estos últimos. La teoría, impulsada durante sus primeras décadas por el argentino Raúl Prebisch, dispuso de un foro de discusión, la Comisión Económica para América Latina y el Caribe (CEPAL), con sede en Santiago de Chile.

46 A propósito de esta cuestión, María Íñigo ha escrito: «El paradigma desarrollista de los cincuenta se traslada al paradigma de la dependencia en los sesenta y setenta. Estas fueron las décadas de definición de un «arte latinoamericano», de la búsqueda de lo auténtico y de la poco fecunda contraposición de lo propio y 
Para el artista, la resistencia a las imposiciones económicas y culturales del centro sobre la periferia debía llevar aparejada una redefinición radical de la esfera cultural de los países dependientes, una «autoafirmación» identitaria en la que la descolonización del saber solo podía suceder a la revolución política:

Para mí un artista de América Latina es, ante todo, un hombre emplazado en una situación particular caracterizada por la dependencia. Una sociedad económicamente dependiente lo es también culturalmente ya que no ha hecho un ejercicio de autoafirmación de ninguna naturaleza (...) Un artista de América Latina (...) está condicionado por una dependencia cultural. No basta que a él no le guste esta situación para que pueda superarla. Ya que ella sólo será superada con un proceso político de base que tienda a la descolonización, un proceso revolucionario, un proceso de absoluta inversión de la situación ${ }^{47}$.

La dependencia cultural que Marta Traba había señalado en la asunción de la vanguardia internacional por un sector del arte latinoamericano ${ }^{48}$ sólo podía superarse en la identificación inicial de la cultura en general y del arte en particular con la utopía de la revolución política. El nacionalismo y el latinoamericanismo descartaban cualquier influencia internacionalista en tanto elemento de penetración cultural. Con el horizonte signado por aquella socialización del arte que habilitara la emergencia de una cultura del pueblo, al artista, a punto de ver desvanecida su figura en el torbellino del cambio social, solo le quedaba la opción de dedicar sus esfuerzos a la invención de una imagen política de, para y al interior de la revolución.

\section{Coda: copar las instituciones}

Por disonante que pueda parecer con los que acabamos de exponer, hay que señalar que estos planteamientos teóricos no impidieron que, en la práctica, tanto Ferrari como Carpani formaran parte puntual y estratégicamente de una tendencia que caracterizó los primeros años de la década del setenta, cuando la Revolución Argentina, al frente de la cual Juan Carlos Onganía fue relevado sucesivamente por Marcelo Levingston y Alejandro Agustín Lanusse, comenzaba a dar síntomas de agotamiento. Nos referimos a un proceso de signo inverso al seguido por los artistas protagonistas de la vanguardia argentina de los años sesenta, consistente, según ha señalado Ana Longoni, en «un retorno a los espacios de la «institución arte» brevemente abandonados en los años previos [por el cual] las instituciones artísticas (...) pasan a ser lugares a ocupar, oportu-

lo ajeno, lo nacional y lo internacional, un debate que todavía hoy tiene ecos en la teoría del arte en América Latina», María ÍÑIGO CLAVO, (Des)Metaforizar la Alteridad: La poscolonialidad en el arte en Brasil durante el AI-5 (1968-1979). Tesis Doctoral inédita, 2009, pág. 96.

47 M. ROJAS MIX (ed.), Luis Felipe Noé. El arte de América Latina es la revolución. Op. cit., págs. 22-24.

48 Marta TRABA, Dos décadas vulnerables en las artes plásticas latinoamericanas, 1950-1970. Buenos Aires, Siglo XXI, 2007. Los ataques al conceptualismo como una moda esnobista y extranjerizante se repiten a lo largo del libro de Traba, quien arremete en diversas ocasiones contra las dos principales instituciones que lo impulsaron en Argentina a lo largo de las décadas de los sesenta y los setenta: el Instituto Di Tella (dirigido por su mentor inicial, Jorge Romero Brest) y el CAYC (Centro de Arte y Comunicación). Con todo, hay que señalar que Traba luchó igualmente por desplazar la imagen del arte latinoamericano de toda connotación exótica y homogeneizante. 


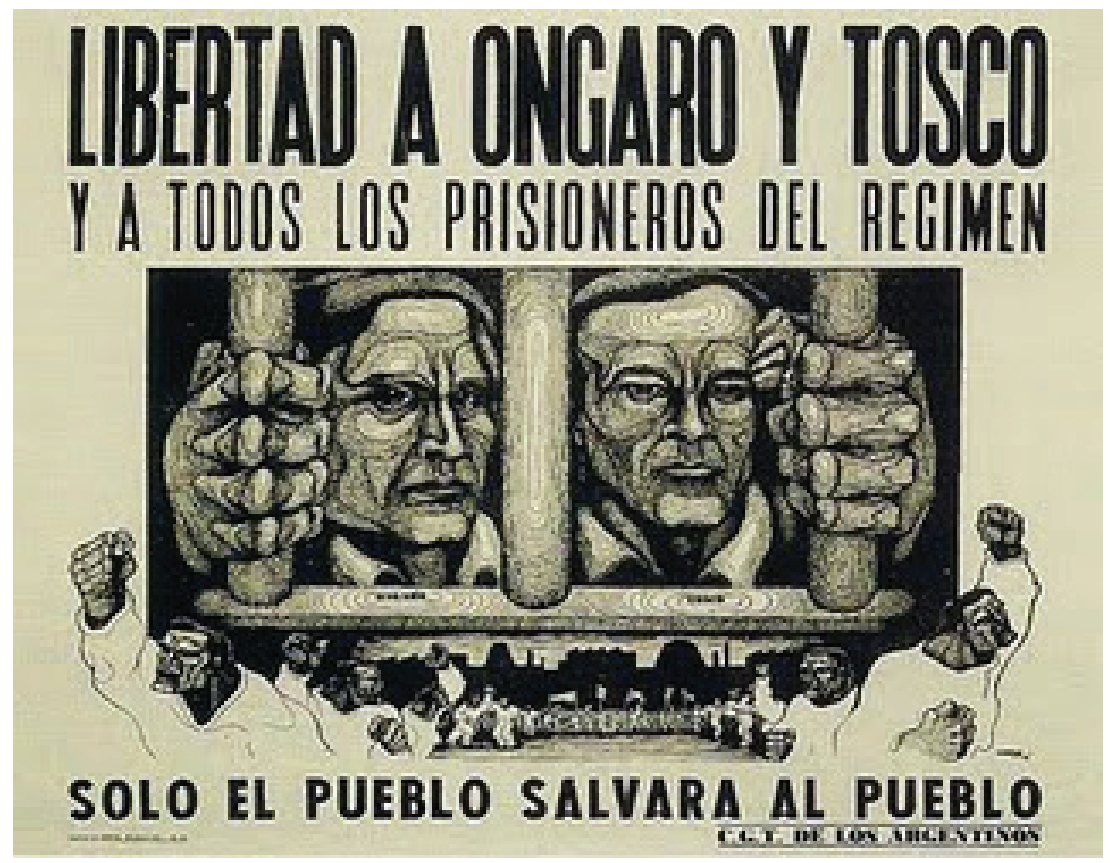

Fig. 8: Cartel diseñado por Ricardo Carpani reclamando la liberación de los dirigentes obreros Raimundo Ongaro y Agustín Tosco, presentado en el II Certamen de Investigaciones Visuales, 1972.

nidades a aprovechar, en el afán de generar ecos amplificados de las denuncias que los cada vez más duros enfrentamientos con la dictadura promovían ${ }^{49}$. Así, con ocasión del II Certamen de Investigaciones Visuales, celebrado en el Palais de Glace de Buenos Aires en 1972, Carpani y Ferrari presentaron dos obras que fueron rechazadas por el jurado encargado de otorgar los premios ${ }^{50}$. El título de la propuesta de Carpani parecía mofarse deliberadamente de la institucionalización padecida por las experiencias del arte de los medios, que con tanta fuerza habían irrumpido en los sesenta, y su aspiración por desentrañar y reconfigurar en sentido contrario las claves ideológicas que guiaban la comunicación de los medios de masas. Bajo los títulos de «Experiencia de comu-

49 A. LONGONI, «Investigaciones Visuales en el Salón Nacional (1968-1971): la historia de un atisbo de modernización que terminó en clausura», Marta Penhos y Diana Wechsler (coord.), Tras los pasos de la norma. Salones Nacionales de Bellas Artes (1911-1989). Buenos Aires, Ediciones del Jilguero, 1999, pág. 203. Pese a remarcar este hecho, Longoni no deja de señalar, en la línea de los expresado más arriba por Ferrari y Carpani, que la actividad de aquellos artistas partícipes de la deriva sesentayochista que insistieron en redefinir la relación entre arte y política se centró mayoritariamente por esos años en la realización de «trabajos gráficos (afiches, cartelones, murales, volantes, historietas) para intervenir en conflictos sindicales, solicitados por la CGT de los Argentinos. La actividad plástica, si no se abandona, aparece puesta al servicio de las necesidades y urgencias de la política», Ibid., pág. 203.

50 Según explica Longoni, el Certamen de Investigaciones Visuales, que tuvo dos ediciones en 1970 y 1971 , fue una derivación de los Salones Nacionales. Desde el punto de vista artístico, el carácter eminentemente conservador de dichos salones no pudo sustraerse a las nuevas modalidades surgidas durante la década de los sesenta, Ibid., págs. 192-193. 
nicación de masas 1»y «Experiencia de comunicación de masas 2» se escondían los carteles que Carpani había confeccionado y difundido a propósito de la detención de los sindicalistas Agustín Tosco y Raimundo Ongaro -ambos figuras clave de la CGT de los Argentinos- y como homenaje a Felipe Vallese, obrero y dirigente peronista desaparecido en 1962 (fig. 8) ${ }^{51}$. Pese a las concomitancias que hemos señalado con la posición de Carpani, Ferrari no renunciaba a ciertas herencias del itinerario de la vanguardia sesentayochista, en concreto a aquellas que se centraban en el trabajo con los medios y el concepto de «contrainformación». El artista remitió al certamen una carta en la que explicaba la finalidad del «rollo de papel» que la acompañaba. Se trataba de elaborar

Un Diario Mural titulado EL CALENDARIO DE LA CASA ROSADA en el que transmitiré informaciones del día sobre los hechos más importantes de la represión que sufre nuestro país. Dado que un diario transmite las informaciones del momento, esta obra solo podrá ser concretada una vez que el salón se haya inaugurado, con las informaciones de ese día, advirtiendo que se modificará y completará cada día que el Salón tenga abiertas sus puertas ${ }^{52}$.

La estructura de la obra, definida procesualmente, vendría determinada por tres tipos diferentes de noticias: en primer lugar, aquellas relativas a la tortura y la represión policial que eran publicadas por los periódicos ${ }^{53}$; en segundo, aquellas que la dictadura impedía que vieran la luz ${ }^{54}$; finalmente, los rollos albergarían noticias relativas a la represión sufrida por los integrantes de la esfera cultural -con especial énfasis en las artes plásticas- y a la connivencia de diversos artistas con el imperialismo a partir de su decisión de participar en eventos patrocinados directa o indirectamente por este último ${ }^{55}$.

El miedo expresado por Ferrari a propósito de la posible recepción autolegitimadora por parte de la institución de su propuesta no fue corroborado por los hechos ${ }^{56}$. A la no admisión de las obras de Carpani y Ferrari se sumó la censura de las instalaciones Made in Argentina, de Ignacio Colombres y Hugo Pereyra - una silueta humana que aludía directamente a la picana como metodología de tortura recurrente del poder de facto-y

51 Ibid., pág. 206.

52 Cfr. Vicente ZITO LEMA, «Del esteticismo al hecho revulsivo. Certamen Nacional de Investigaciones Visuales», Nuevo Hombre, 3 de noviembre de 1971, s. p., Archivo León Ferrari.

53 FERRARI enumeraba las siguientes: «(...) represión policial y parapolicial, torturas, secuestros, desapariciones de presos, sentencias del nuevo Fuero antisubversivo con fotografías de los jueces que lo componen, fotografías e informaciones de los métodos e instrumentos de tortura, protestas individuales y de agrupaciones de estudiantes, obreros, curas del Tercer Mundo, Juntas Vecinales, Frente de Abogados y del nuevo Foro por los Derechos Humanos, etc.». Ibid., s.p.

54 Entre ellas «(...) la huelga de hambre de los presos de Villa Devoto silenciada durante diez días, el secuestro de Cristianismo y revolución silenciado por casi todos sus colegas, conflictos como los que mantuvieron los periodistas de Análisis, denuncias de organismos como el Movimiento contra la Represión y las Torturas y otros organismos formados por familiares de presos políticos como Ongaro, el pintor Eduardo Ruano, testimonios de los torturados, represión en las Villas Miseria, etc.». Ibid., s. p.

55 A propósito de esta última cuestión, Ferrari mencionaba exposiciones nacionales como «Ejército y cultura» o «Arte de sistemas» y eventos internacionales como la Bienal de São Paulo.

56 LONGONI destacaba que «Ferrari cierra su carta-descripción de la obra planteando que al presentarse a un Salón oficial, la obra «corre el riesgo de integrarse al arte del régimen, de hacer las veces de señalador de tolerancia»», A. LONGONI, «Investigaciones Visuales en el Salón Nacional (1968-1971): la historia de un atisbo de modernización que terminó en clausura», Op. cit., pág. 207. 
Celda, de Gabriela Bocchi, que reproducía una lista de los presos políticos encerrados en las cárceles de la dictadura ${ }^{57}$. Ambas obras, que obtuvieron, respectivamente, el Gran Premio de Honor y el Primer Premio, trataban de despertar un sentimiento de empatía en el espectador ${ }^{58}$. Se presentaban como formas de disenso político que, al tiempo que otorgaban visibilidad a hechos de los que se tenía mayor o menor consciencia social, vulneraban la normalidad de los contenidos que el régimen consideraba oportunos para el ethos que asignaba a la esfera cultural. El Decreto del Poder Ejecutivo Nacional $\mathrm{n}^{\circ}$ 5696/71 planteaba con rotundidad que las obras galardonadas tenían «una clara intención política ajena al contenido y al espíritu que debe animar a este tipo de concursos artísticos $\rangle^{59}$. En el decreto, la procelosa descripción de las obras se esforzaba por fijar unívocamente su sentido. Se trataba de reducirlas injusta e inexactamente al concepto de propaganda, de manera que se pudieran identificar las posiciones ideológicas que se escondían tras la denuncia ${ }^{60}$. De esta manera, el poder militar no hacía sino atestiguar y reproducir la carencia de libertades que las obras apuntaban de modo más indirecto ${ }^{61}$; una carencia que pocos años después, cuando los sueños revolucionarios empezaron a toparse con su límite histórico, adoptaría los rasgos terroríficos del genocidio de Estado.

57 Algunos de los participantes en el certamen, como el propio Colombres, incursionaban por primera vez en este tipo de modalidades artísticas. Al recoger un testimonio del artista, Ana Longoni añade: «(...) hay un matiz que me interesa señalar: el reconocimiento de muchos artistas de la efectividad mayor que lograban ciertos desarrollos del arte experimental en relación al que podían tener los formatos y los modos de representación tradicionales en su impacto sobre la esfera política», Ibid., pág. 216.

$58 \mathrm{Ibid}$., pág. 217. Para ello, Celda incluía en su interior un espejo que hacía que el espectador se viera reflejado en él como si, por un momento, pasara a engrosar la lista de presos políticos adjuntada. Una estrategia similar había sido empleada por Jorge Carballa en la obra Réquiem para la libertad, con la que obtuvo el premio del jurado -del que formaron parte los críticos Jean CLAY y Lucy LIPPARD- en la exposición «Materiales, Nuevas Técnicas, Nuevas Expresiones», celebrada en el Museo Nacional de Bellas Artes en 1968. Allí presentó una mesa de gran tamaño en la que incluyó una serie de espejos rectangulares en los que el espectador podía ver reflejado su rostro. Un cartel situado en uno de los lados de la mesa aclaraba que «en estos espejos se han reflejado los rostros de condenados en diferentes establecimientos penitenciarios de nuestro país», cfr. Guillermo WHITELOW, «Carta de Buenos Aires», Art International, volumen XIII/ 5, mayo de 1969, pág. 28.

59 Cfr. Alberto GIUDICI, Arte y política en los 60. Buenos Aires, Fundación Banco Ciudad/ Palais de Glace/ Secretaría de Cultura, 2002, pág. 269.

60 Ibid., págs. 269-270. Según resaltara Ana LONGONI, «el PEN [Poder Ejecutivo Nacional] se tomó la increíblemente burocrática molestia de investigar uno por uno los nombres de la «Nómina incompleta de detenidos políticos y sociales al 4/10/71» que acompañaba la obra «Celda» de Bocchi y Santamaría. En el expediente figura el informe oficial que explicita la situación de cada preso, el lugar de su detención y -sobre todo- el motivo de la misma», A. LONGONI, «Investigaciones Visuales en el Salón Nacional (1968-1971): la historia de un atisbo de modernización que terminó en clausura», Op. cit., pág. 208.

${ }^{61} \mathrm{El}$ altercado dio lugar a una reacción de la SAAP en defensa de los artistas. La organización remitió una carta a la Academia de Bellas Artes en la que se quejaba de su dejación de funciones, al no haber emitido una respuesta a la decisión del PEN: «Nuestra protesta quiere señalar la actitud del llamado ente rector de las Bellas Artes, su academia Nacional, que se supone que entre otras cosas, aparte de otorgar premios, debe preservar la actividad artística de todo intento de censura», cfr. A. GIUDICI, Arte y política en los 60. Op, cit., pág. 279. Por otra parte, un grupo de artistas se negó a participar en la Exposición Itinerante de Grabado Argentino organizada por la Cancillería de la Nación, cfr. Ibid., pág. 280. Para la siguiente edición del Salón, el Grupo Manifiesto (Diana Dowek, Daniel Costamagna, Alfredo Saavedra, Magdalena Beccarini, Fermín Eguía y Norberto Maylis), de tendencia maoísta, organizó un Contrasalón, que a escala nacional reproducía la iniciativa de la Contrabienal de 1971, un proyecto bibliográfico impulsado por artistas latinoamericanos residentes en Nueva York que denunciaba los nexos entre la dictadura brasileña y la Bienal de São Paulo. Cfr. A. LONGONI, «Investigaciones Visuales en el Salón Nacional (1968-1971): la historia de un atisbo de modernización que terminó en clausura», Op. cit., pág. 213. 